Relations industrielles

Industrial Relations

\title{
The Thought of Work, By John W. Budd, Ithaca: Cornell University Press, 2011, 247 pp., ISBN: 978-0-8014-4983-3.
}

\section{Rafael Gomez}

Volume 67, numéro 2, printemps 2012

URI : https://id.erudit.org/iderudit/1009094ar

DOI : https://doi.org/10.7202/1009094ar

Aller au sommaire du numéro

Éditeur(s)

Département des relations industrielles de l’Université Laval

ISSN

0034-379X (imprimé)

1703-8138 (numérique)

Découvrir la revue

Citer ce compte rendu

Gomez, R. (2012). Compte rendu de [The Thought of Work, By John W. Budd, Ithaca: Cornell University Press, 2011, 247 pp., ISBN: 978-0-8014-4983-3.]

Relations industrielles / Industrial Relations, 67(2), 331-333.

https://doi.org/10.7202/1009094ar

Tous droits réservés @ C Département des relations industrielles de l’Université Laval, 2012
Ce document est protégé par la loi sur le droit d'auteur. L'utilisation des services d’Érudit (y compris la reproduction) est assujettie à sa politique d'utilisation que vous pouvez consulter en ligne.

https://apropos.erudit.org/fr/usagers/politique-dutilisation/ 
Finalement, la troisième et dernière partie de l'ouvrage, consacrée à l'examen des stratégies des acteurs français et européens relativement à la question du travail intérimaire, enchaîne une série d'études de cas permettant de mettre en lumière l'incidence de ces stratégies d'acteurs sur les formes nationales d'intérim. On retrouve successivement un chapitre décrivant le rôle du PRISME (une association de plus de 600 entreprises françaises représentant $90 \%$ du chiffre d'affaires de la profession) dans le développement du statut des intérimaires français (François Roux), un chapitre traitant de la représentation syndicale des intérimaires français mettant plus spécifiquement l'accent sur le rôle de la CGT (Bertrand Fribourg) ainsi qu'un chapitre exposant I'histoire de l'intérim belge, intéressante à plus d'un égard du fait notamment que les pouvoirs publics conçoivent le travail intérimaire comme un authentique instrument de la politique publique de lutte contre le chômage (Jan Denys). Enfin, on retrouve dans les deux chapitres bouclant cette ultime section une étude des pratiques de GRH dans les entreprises de travail temporaire luxembourgeoises (Régis Rouyer) ainsi qu'un examen approfondi de la stratégie des acteurs sociaux au niveau européen (James Arrowsmith).

Bien construit et offrant une contribution substantielle à la saisie d'un objet encore très peu étudié au Québec et au Canada, cet ouvrage intéressera certainement les spécialistes du travail atypique ainsi que les praticiens des politiques du travail et de l'emploi et, dans une optique plus large, tous ceux qui se préoccupent de la situation des travailleurs vulnérables ou précaires. Par son ampleur, la qualité des contributions ainsi que la diversité de cas nationaux qu'il propose, il nous semble acquis que l'ouvrage deviendra rapidement un incontournable pour quiconque s'intéresse de près à cet objet d'étude. On regrettera cependant I'absence d'un véritable cadre comparatif qui aurait permis de faire ressortir puis de comparer les dimensions " objectives» des conditions concrètes de l'emploi intérimaire, cela dans le but de faire ressortir les principales différences entre les États à cet égard. Dans le même sens, une attention plus grande portée aux définitions des concepts se serait avérée utile pour le lecteur nordaméricain. En effet, maints problèmes de traduction et d'interprétation sont soulevés par la diversité des concepts employés dans la littérature administrative et scientifique pour aborder ces réalités et les définitions parfois différentes données à ces concepts en Europe et en Amérique.

\section{Jean-Nickolas Dumaine}

Université Laval

\section{The Thought of Work}

By John W. Budd, Ithaca: Cornell University Press, 2011, 247 pp., ISBN: 978-0-8014-4983-3.

Few expressions of the imbalance inherent in the employee-employer relationship can surpass the one provided by the supposed patriarch of free-market economics, Adam Smith:

[What are the common wages of labour depends everywhere upon the contract usually made between those two parties, whose interests are by no means the same.] The workmen desire to get as much, the masters to give as little...The former are disposed to combine in order to raise, the latter in order to lower, the wages of labour. It is not, however, difficult to foresee which of the two parties must, upon all ordinary occasions, have the advantage in the dispute, and force the other into a compliance with their terms... In all such disputes, the masters can hold out much longer. A landlord, a farmer, a master manufacturer, or merchant, though they did not employ a single workman, could generally live a year or two upon the stocks, which they have already acquired. Many workmen 
could not subsist a week, few could subsist a month, and scarce any a year, without employment. In the long run, the workman may be as necessary to his master as his master is to him; but the necessity is not so immediate (p. 65).

John W. Budd is one of North America's finest modern Industrial Relations (IR) scholars, and he is careful to salt his engrossing and enlightening narrative on our collective conceptualizations of work with these often surprising quotes from otherwise well-known writers. Over ten economically written chapters, Budd distills what major social science disciplines, the humanities and even religious texts, have had to say about work in order to, in his words, "provide the basis for thinking about what work means to us as individuals, and what we value as a society." He correctly identifies the twentieth century obsession with "paid employment" and our current fascination with "new economy narratives of work" while pointing out that these views in fact privilege economic-based interpretations of work as production and, at the same time, diminish conceptualizations that "sustain the health and welfare of individuals, families and communities" (p. 18).

Most conceptualizations of work are so ingrained in their respective academic fields that they often remain unarticulated and therefore unknown to outsiders. Because of this, Budd ranges across a wide array of disciplines and makes their notions of work explicit. An understanding of these various views of work is essential because how we think about work ultimately reinforces the nature of work in practice. Some readers might take issue with Budd's assertion that thoughts of work do more than just reinforce structurally determined patterns of labour arrangements, and instead can actually affect how work is conducted. Budd explicitly states: "If work is seen as a commodity, it will be left in the hands of the marketplace" whereas if "work is seen as a source of personal fulfillment, it will be structured to provide that fulfillment" (p. 17). But if this is the case, how is it that our notions of work change and evolve through time? Are these changes really due to 'collective shifts' of consciousness? A more likely possibility is that material conditions evolve in such a way so as to favour a particular, often unstated or unarticulated, view of what work means in a given time and place. Budd never fully resolves this particular issue, but then again that is not his intent.

By presenting his readers with a comprehensive account of the diverse conceptualizations of work that have appeared throughout history and that vary across disciplines, Budd hopes that the specific conceptualizations embraced by a particular society should be subject to critical examination and more importantly, perhaps, subject to change. Indeed, as Budd points out, it is of no minor significance that in the United States - where the notion of work as a commodity rides paramount housework and child care are not deemed worthy of earning social benefits and volunteers are excluded from protections against discrimination that protect paid workers. As compared to other countries at similar levels of development, Budd shows us that this is a rather unique state of affairs. Readers may come away convinced that this is indeed a case where unpaid work is literally 'devalued' because of the way work is viewed in the US (something that is not the case in neighbouring Canada, which is materially very much the same). In this sense, conceptualizations of work do seem to matter in the way Budd asserts.

As noted by Budd in his introduction, the "long-standing Western vision of work as a way to achieve...mastery... of the natural world....arguably provides the seed for excess consumption and environmental degradation" (p. 18). These are clearly ideas of major interest not only to academics, but to anyone who is remotely interested in bettering life on this planet, a 
point reiterated often in the book. This is why for employment relations readers the most novel and compelling conceptualizations of work may well be those that appear in the second half of the book. While the first half of the book (chapters 1 through 5) ranges over concepts that most labour market researchers would find familiar (i.e., work as a 'curse', 'freedom', 'commodity', 'occupational citizenship', and as 'disutility'), chapters 6 through 10 (i.e., work as 'personal freedom', a 'social relation', 'caring', 'identity', and 'service') reveal the rich intellectual debt owed to scholarship that lies outside of the traditional employment relations paradigm.

In one of the most compelling chapters (chapter 10), Budd elucidates his readers on the notion of work as 'service'. He exposes a lively branch of theological thinking that dates back, literally, to the 'Garden of Eden'. $\mathrm{He}$ also squares a circle that has been difficult for many to understand; namely the split personality that many religions have with the notion of 'work'. At once highly praising labour effort, the Bible seems to be endorsing the cult of hard work that has enveloped the West. Yet there is also a tension inherent in the idea of work intruding on the time allocated for service to family, community and ultimately to God. How can these contradictory stances be reconciled?

Budd identifies the source of the tension: individualism. Citing theological scholars, he points out that the modern worship of 'work-hard/play-hard' has "little to do either with worship or God or with God's demands on human life; it has much to do with 'worship' of self and human demands on the self" (p. 176). Attempts by modern religious scholarship and teaching to redraw the focus away from the self towards the community can be seen, in Budd's words, as an attempt to temper the "overly individualistic and selfish conceptualizations of work" that are pervasive in Western societies today. As Budd sums the matter up, long-standing tensions between community and individual are brought to the surface in our understanding of work as service and in the totality of what work 'truly means' for us as individuals and as parts of society.

After showcasing the 10 conceptualizations of work - in what is perhaps the only major criticism readers may be left with - the book offers only a few pages (p. 181-185) of room explicitly stating how these conceptualizations matter. Whether in policy debates about labour laws or whether in our choice of business practices, Budd could have done more to show how each of his explicit revelations of work can be used in practical and policy relevant ways. Readers who are left wanting more may want to pick up on this last theme by reading engaging treatments of work as documented by writers who interview actual participants; I am referring here to classic texts by Studds Terkel or modern variants by Barbara Erenreich and Alain de Botton.

We spend most of our lives working - in occupations often determined by circumstance or chosen by our inexperienced younger selves - and yet we rarely ask ourselves how we got there and what our occupations mean to us. The Thought of Work affords readers an opportunity to delve into the meaning(s) of work and catch our collective breath just long enough before the next work day begins.

\section{Rafael Gomez}

University of Toronto

\section{L'économie de la fonctionnalité : une voie nouvelle vers un développement durable ?}

Sous la direction de Gérald Gaglio, Jacques Lauriol et Christian du Tertre, Toulouse : Éditions Octares, 2011, 198 p., ISBN : 978-29153-4693-0.

Les contributeurs de ce petit ouvrage dense et original se sont fixés l'ambitieux objectif d'exposer les modes par lesquels on peut évaluer l'apport de biens et services dans une approche, relativement nouvelle, de développement durable. D'abord mise de 